\title{
Determinants of Improving the Strategy of Sustainable Energy Management of Building Sustainable Value for Stakeholders-Experience of Organizations in Poland
}

\author{
Aneta Wysokińska-Senkus (D)
}

Citation: Wysokińska-Senkus, A. Determinants of Improving the Strategy of Sustainable Energy Management of Building Sustainable Value for Stakeholders-Experience of Organizations in Poland. Energies 2021, 14, 2878. https://doi.org/ 10.3390/en14102878

Academic Editor: T. M. Indra Mahlia

Received: 12 April 2021

Accepted: 11 May 2021

Published: 17 May 2021

Publisher's Note: MDPI stays neutral with regard to jurisdictional claims in published maps and institutional affiliations.
Institute of Management, Management and Command Faculty, War Studies University, 00-910 Warsaw, Poland; a.wysokinska-senkus@akademia.mil.pl

\begin{abstract}
The purpose of the research was to identify the factors determining the improvement of the sustainable energy management strategy in the process of building lasting value for stakeholders, identifying key activities supporting the process of improving the sustainable energy management strategy, and analyzing the degree of use of environmental indicators by organizations in Poland. In the research process, to achieve the assumed research goals, it was decided to use the following research methods: The "Delphic Method" and the CAWI method (Computer-Assisted Web Interview). The research was carried out on a sample of 102 organizations in Poland. The study identifies goals for the sustainable development of the organization, activities supporting the process of sustainable energy management, and indicators in the field of energy management. The key factors for the improvement of energy management strategies have been identified, including implementation of modern technologies, reduction of energy consumption, development of procedures, increase of employee awareness, and clearly defined goals in the field of energy management. The strategy of the organization's future actions towards achieving sustainable development determines the process of creating value for stakeholders. Dialogue with stakeholders is one of the basic conditions for proper planning and implementation of the organization's strategy and taking actions in the field of sustainable energy management. Effective energy management becomes a necessity. Organizations must take a number of steps to achieve maximum resource efficiency. This can only be achieved through a holistic approach to the process of formulating the goals of the organization, which is necessary in decision-making processes and in the approach to energy management. The Polish economy has been built on coal and other fossil fuels. So far, the majority of polish organizations have not cared about the natural environment and energy management, which is why the research on redefining their strategies is a novelty.
\end{abstract}

Keywords: sustainable energy management; strategy; stakeholders; sustainability

\section{Introduction}

In countries like Poland, which have recovered from communist economies where enterprises have been putting a lot of effort into economic growth but leaving aside the problems related to the natural environment, energy efficiency, and energy management, there especially is a need for research aimed at improving the improvement of sustainable energy management strategies in building lasting value for stakeholders. The analysis of the literature on the subject shows that despite the enormous achievements of management sciences, there are few items that would deal with this issue in a holistic approach.

Organizations often disregard the strategic opportunities that may arise from the application of the principles of sustainable development of the organization. In order to achieve an increase in shareholder value, organizations should use the principle of sustainability in the processes of creating shareholder value and generating profits. Managers should directly link the two goals of striving to achieve corporate stability and creating shareholder value. 
Sustainable energy management is one of the top-priority goals of modern organizations. Thanks to the focus on energy management and effective energy management, many important benefits for the organization can be achieved. These include the possibility of identifying and managing the risk related to future energy supply, measuring and monitoring energy use, identifying areas requiring improvement in efficiency, increasing overall efficiency, building beneficial relationships with the organization's stakeholders by proving concern for the environment, and implementing the assumptions of the sustainability concept.

Because of the importance of environmental management issues, the aim of this study is to identify the factors determining the improvement of the sustainable energy management strategy in the process of building lasting value for stakeholders.

The aims of the research were:

(a) To highlight the role of stakeholders in strategy developing process-the stakeholders, especially customers, in their relations with organizations are more and more focused on taking care about the activities that their partners undertake in the area of environmental management including energy management and efficiency;

(b) To highlight the strategy management frameworks that could be used as fundamentals to develop strategy by any organization - the organizations that have their origin in post-communist countries and developing countries have been developing mostly in the economic perspective, leaving aside ecological and social issues. Nowadays, the issues that were not so important have become crucial, but the organizations still do not have the tools and/or knowledge to implement all important issues in their strategies;

(c) To identify the key factors in improving your sustainable energy management strategy according to the surveyed organizations;

(d) To identify the key actions supporting the process of sustainable energy management according to the surveyed organizations;

(e) To identify the environmental indicators used by organizations and what their degree of use and sustainability in the organization is according to the surveyed organizations;

\section{Material and Methods}

To fulfill the aims of the paper, being (a) to highlight the role of stakeholders in strategy developing and (b) to highlight the strategy management frameworks that could be used as fundamentals to develop strategy by any organization, in-depth literature research was done. The material for the desk research consisted of articles and books published in the subject of management field.

To fulfill the aims of (c) identifying the key factors in improving sustainable energy management strategy, (d) identifying the key actions supporting the process of sustainable energy management, and (e) identifying the environmental indicators used by organizations and their degree of use and sustainability in the organization, the primary research was done, and the main research aims were met.

In the research process, it was decided to use the following research methods to achieve the assumed research goals:

- The "Delphi method" and "Brain Storming"-20 experts from management fields and leading organizations have helped to develop the survey questionnaire that were used in CAWI, helped to select proper frameworks for strategy development, and helped to analyze CAWI results;

- $\quad$ The CAWI method (Computer-Assisted Web Interview) - the survey consisted of 25 questions related to the organization's strategy and the operational priorities. The questions were mainly based on the Likert scale and ordinal scale. One hundred and twenty organizations from Poland took part in the CAWI.

The main motive for using the Delphi method in the research was the fact that the experience of many institutions, including SAS Institute Inc. [1], shows that research and 
analyses using methods involving the participation of experts in a given field often give better results than research and analyses performed with the use of statistical methods.

The "Delphi method" was supported by a survey questionnaire created using the CAWI (Computer-Assisted Web Interview) method.

In order to achieve the set research goals, the following research process scheme was proposed.

The research steps are presented on Figure 1.

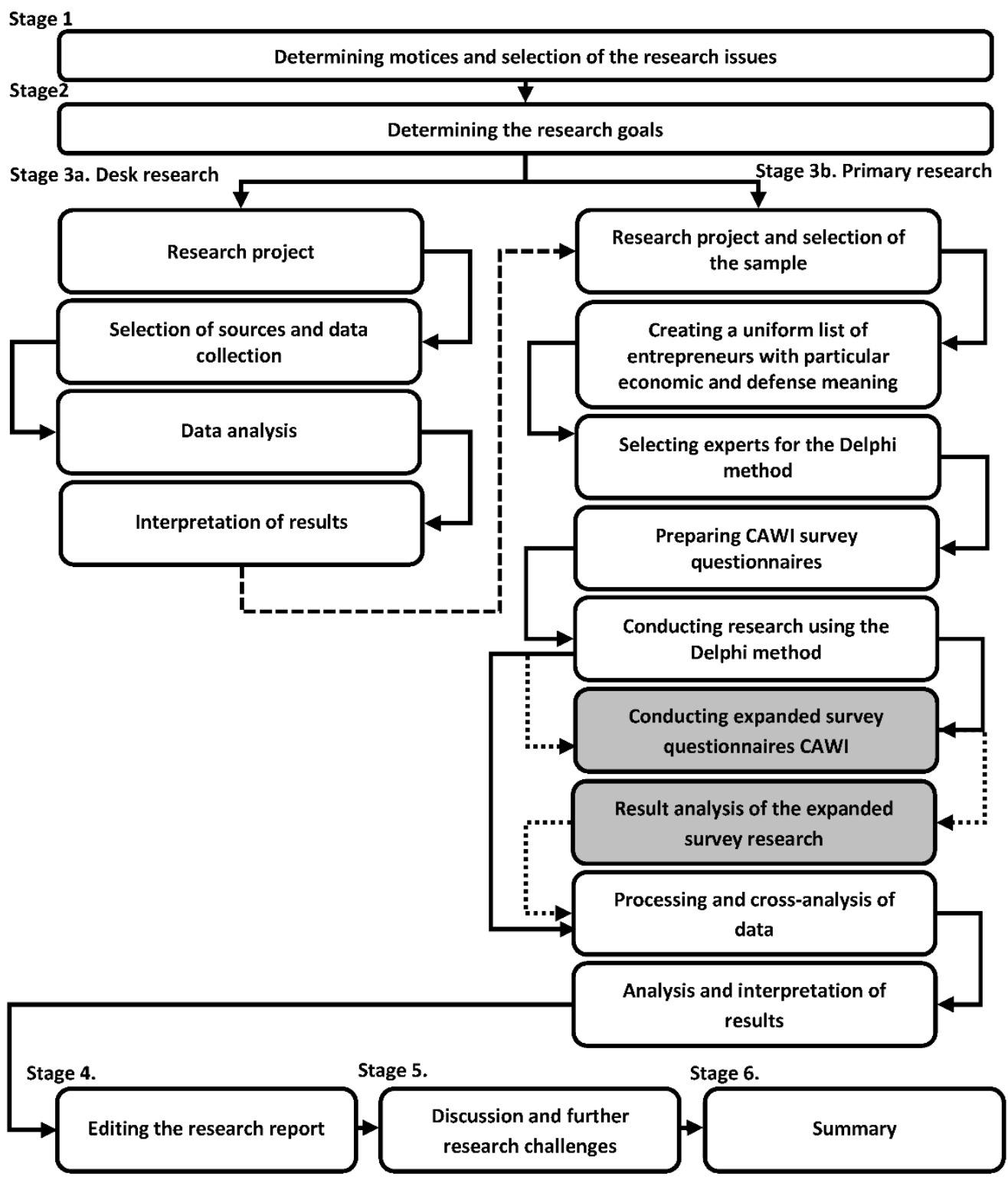

Figure 1. Scheme of the research process. Source: Own study, 2021.

CAWI (Computer-Assisted Web Interviews) research is a method of obtaining data using an online questionnaire made available to respondents. In the case of this study, the online questionnaire was addressed to a strictly defined target group, i.e., experts invited to the panel of experts.

According to the literature on the subject, the strength of the application of the CAWI method is the reduction of the time and costs of preparing the study, as well as its implementation and preparation of data for analysis [2-5].

One of the main factors that determined the choice of this research method was a very wide range of issues that could be difficult to recall during a direct interview with 
the interviewer. Another factor supporting the choice of this method was the fact that all entities selected for the study had fast Internet access.

\section{Results and Discussion}

\subsection{The Role of Stakeholders in Improving the Management Strategy}

Considering the needs and expectations of stakeholders in the strategy of the organization is of significant importance in increasing the effectiveness of the organization. According to Courtney Pratt (Former CEO Toronto Hydro), business, apart from its primary responsibility towards stakeholders, should respond to the needs of other key stakeholders, such as clients, employees, NGOs, government, and local community.

The organization's efforts to achieve long-term positive outcomes oblige the implementation of a continuous improvement strategy to be implemented that would be directed at meeting the requirements of stakeholders. Therefore, organizations should constantly analyze threats that may appear in the process of building relationships with stakeholders [6].

Authors like Harrison and Caron [7] or Freeman [8] have introduced the view that the expectations of stakeholders in the examined organization are important, they effect the organization's strategy, and knowing and fulfilling them determines success. Management should recognize that they change over time and require further analysis by the organization executives.

Carroll [7] is of the opinion that the organization's management should recognize the different groups or shareholders in the decision-making process of the organization and focus on their needs and expectations and take them into consideration in the strategic planning process.

Harrison and Caron [7] have grouped entities operating in the organization (owners and/or management, managers, and employees) and outside the organization (clients, suppliers, governmental and NGOs, unions, competitors, financial intermediaries, local communities) and all bodies operating within the wider environment of the organization: Socio-cultural, economic, political, legal, and technological. They highlight the importance of identifying and understanding the needs and expectations of its key stakeholders and setting positive relationship with stakeholders, including the formulation of organizational strategy.

Yetton and Vroom [9] specify several models that present stakeholder participation in decision making in an organization:

- Mostly, decisions are made autonomously by the company manager, who does not take into account the stakeholders.

- The manager looks for information and suggestions from some stakeholders but finally decides himself in a way that may or may not reflect stakeholder views.

- The manager analyzes a decision problem separately from each stakeholder's point of view. They listen to stakeholders' ideas and suggestions, and then make decisions, that include the point of view of the specific stakeholder.

- The manager consults the problem with stakeholders, then includes their ideas and suggestions and carries out the decision-making process.

- The manager makes decisions in consultation with stakeholders. The task of the board of the organization is to focus on setting the new strategy of the organization.

\subsection{The Essence of the Concept of Sustainability, Determinants of Designing a Sustainable Organization}

The challenges related to sustainability, recognized through the prism of well-defined business goals, help identify strategies and related goals, which lead to a more sustainable world and, at the same time, deliver value to owners, which is related to creating sustainable value.

Most managers do not see the benefits of sustainability [10]. Sustainable development of the organization, meanwhile, aims to create long-term value for shareholders through the 
use of opportunities and risk management that relates to economic aspects, environmental aspects, and social responsibility [11].

Sustainability from a business point of view means an active approach to achieving the long-term economic outcome of the organization and the integrity of the activity by minimizing the use of necessary resources, reducing environmental impact and energy use, minimizing the negative impact on the social environment and resource management, while maintaining the long-term profitability of the organization.

It is the ability of the enterprise to continuously improve their skills to maintain and improve position on the market by offering extraordinary value to its current and future clients, thanks to organic volatility constituting business models, and resulting from creating new opportunities and goals and responding to them, while balancing the interests of various stakeholders [12].

For many leaders of corporate sustainability organizations, it has become an invaluable way to cut costs, neutralize risk, design new products, and generate changes in the organization's culture, processes, and structure. Azapagic points out, however, that achieving corporate sustainability is not an easy task. Incorporating the practice of sustainable development into the organizational structure is not a simple formality, as it requires the development of a vision, employee involvement, and effective leadership. The condition is also a systemic approach with the development of an appropriate management framework that will enable the design, management, and communication in the organization with regard to the implementation of sustainable development policy [13,14].

The European Commission has defined a set of indicators to monitor the implementation of the sustainable development strategy. Its basic goal is to examine the current advancement of the strategy implementation [15].

The trends derived from the analysis of indicators [16] are assessed from the perspective of the objectives. This mapping is done to inform stakeholders and decision makers about the achievements or failures of the sustainable development goals perspective.

According to Seliger $[17,18]$, sustainable development is aimed at improving human living standards while improving the accessibility of natural resources and ecosystems for future generations.

The orientation of the organization on the integration of ethical, social, environmental, and economic aspects favors active activities in the field of accounting, consisting in isolating the impact of the organization on the environment and social environment, beyond the already existing economic account.

There are four sets of factors that contribute to global sustainability. The first set concerns increasing industrialization and is related to material consumption, pollution, and waste generation [19]. The industrialization process brought enormous economic benefits, but also caused a significant pollution burden [20]. Increasing resource efficiency and preventing pollution are key to sustainable development and constitute the first set of factors. Organizations can create value by reducing material consumption and pollution.

The second set of factors relates to how information is disseminated and how the different stakeholder groups relate to each other. The advancement of Internet technologies has made it possible for these groups to communicate with each other. Sustainable development therefore encourages companies to act in a transparent manner due to well-informed, active stakeholders. Organizations can create value by acting transparently and responding quickly to the needs of individual stakeholders [21].

The third set of factors relates to new technologies that can reduce the negative impact on the environment [22]. Genetic engineering, nanotechnologies, information technologies, and the use of renewable energy sources have a huge impact on reducing the negative impact of humans on the environment. The use of modern technologies leads to the minimization of the amount of waste. Organizations can create value by developing new technologies that lead to a reduction in the environmental impact of human activities.

Finally, a fourth set of factors relates to social phenomena: Population growth, poverty, and income inequality related to globalization. Organizations can create value by meeting 
the needs of social groups at the bottom of the world's income pyramid through wealth creation and distribution [23].

Figure 2 presents the key aspects of sustainability in organizations [24]. Organizations should take measures to integrate the following aspects of functioning with setting goals for the improvement of each of them: Occupational health and safety, employment, supply chain, social issues, resources, image of the organization, legal aspects, risk management, waste management, and energy management. Taking into account the above-mentioned aspects enables the organization to implement the concept of sustainability.

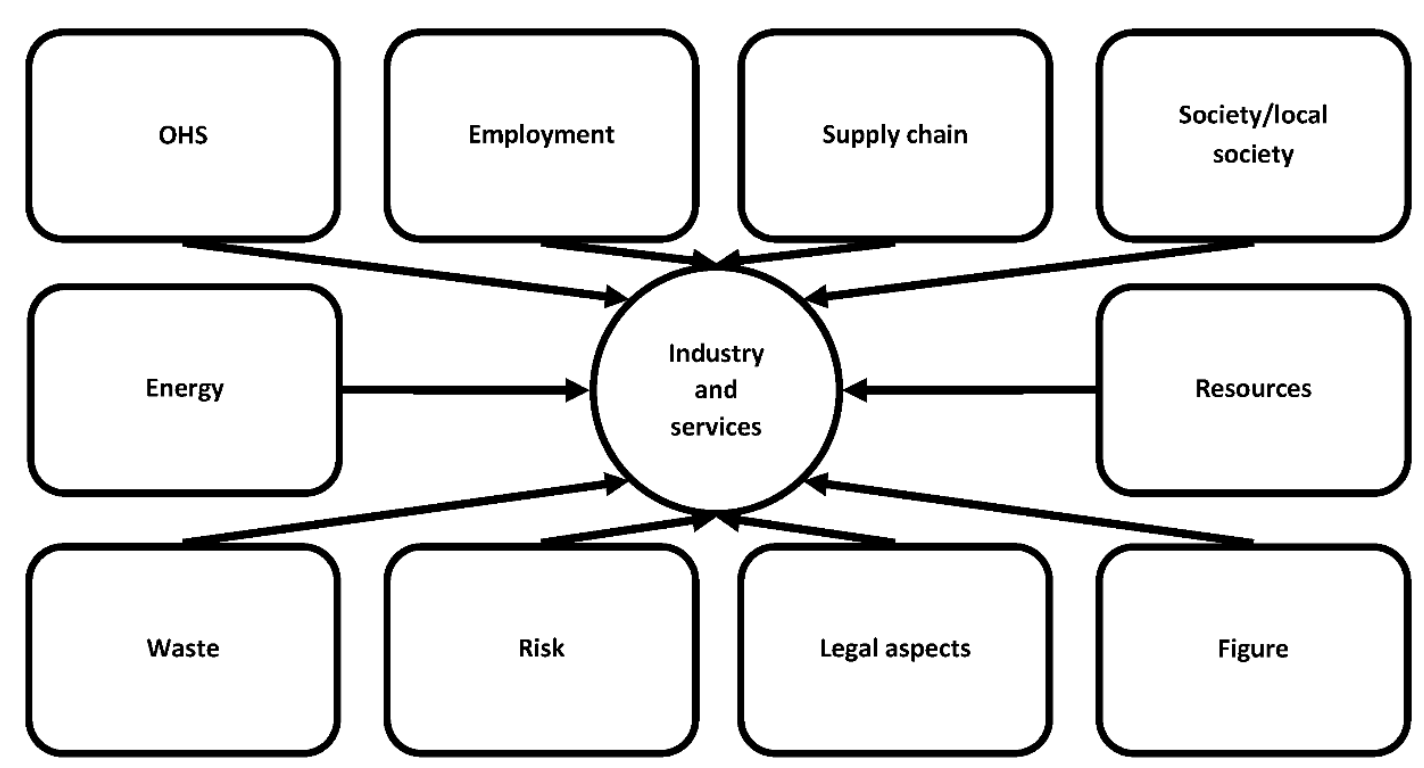

Figure 2. Key aspects of sustainability in organizations. Source: Own study based on, Holton I., Glassb J., Priceb A., Managing for sustainability: findings from four company case studies in the UK precast concrete industry, Journal of Cleaner Production, Volume 18, Issue 2, January 2010, pp. 152-160.

The concept of sustainability plays an important role in formulating the mission of the organization. It is its driving force and is the basis for making decisions [25].

Figure 3 presents the model of designing a sustainable organization. It shows that organizations that strive to implement the concept of sustainability should focus their activities on creating value both for the organization and for individual groups of stakeholders. This is possible if the organization identifies individual groups of stakeholders and determines the expectations and needs for each of them, which will contribute to generating a specific value for them. The organization should also define economic, social, and ecological goals, taking into account the needs of individual groups of stakeholders, and stimulate the activities of stakeholders in order to involve them in the functioning of the organization. Management based on the involvement of stakeholders is a broader approach to participatory management, which from its beginnings, i.e., the works of Elton Mayo "The Human Problems of an Industrial Civilization" (1933) and Kurt Lewin "Frontiers in Group Dynamics" (1947), has been extensively described. Management based on the involvement of employees and other stakeholders can be seen as democracy within the organization.

Emerson states that the relationships between the various stakeholders in business should be based on mutually beneficial relationships. This means that a fair system of cooperation with stakeholders (employees, suppliers, contractors) should be established. In practice, this principle translates into, among others, ensuring decent working conditions, appropriate remuneration, respectful behavior (relations with employees) as well as clear and fair rules of cooperation related to the determination of prices and delivery dates (relations with clients) [26]. 


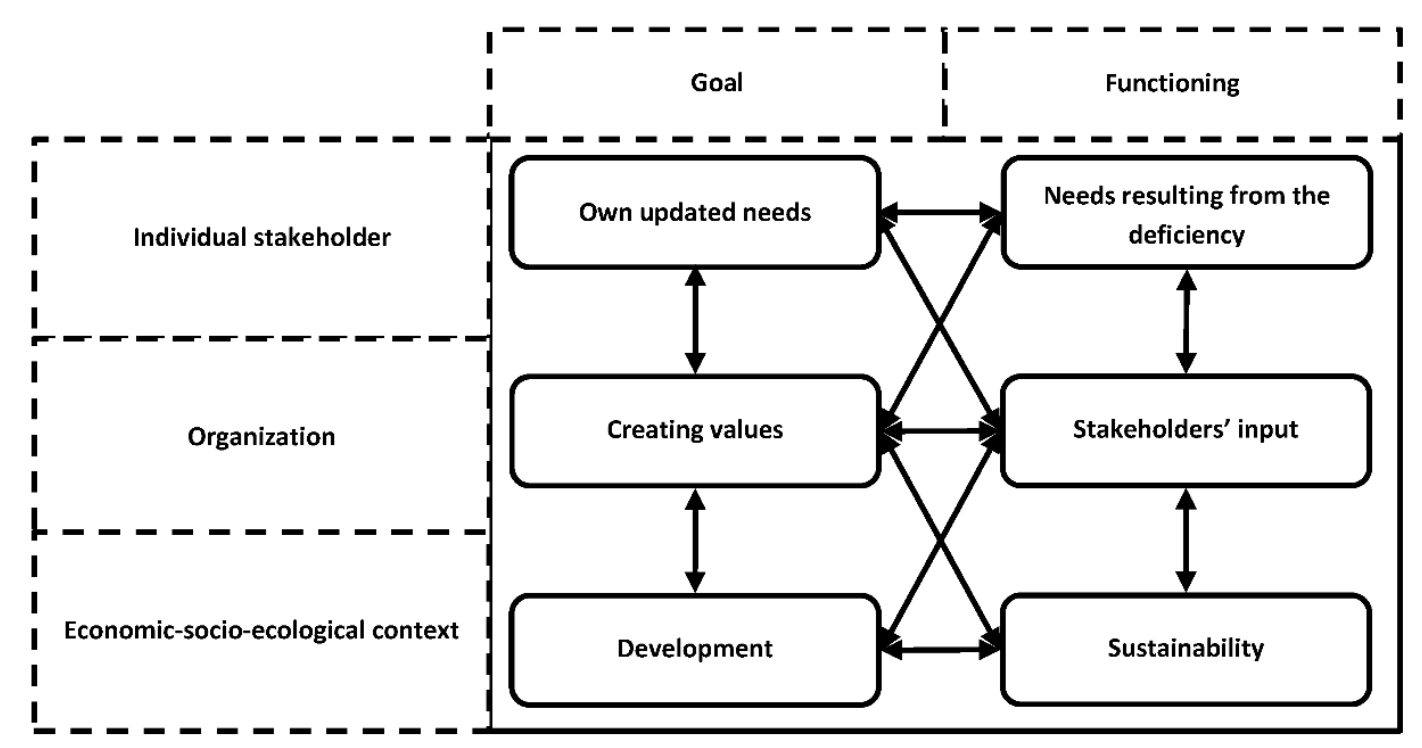

Figure 3. Sustainability enterprise design model. Source: Own study 2012, based on: A.M. Genaidya, R. Sequeira, T. Tolaymat, J. Kohlerc, S. Wallace, M. Rinder, Integrating science and business models of sustainability for environmentallychallenging industries such as secondary lead smelters: a systematic review and analysis of findings, Journal of Environmental Management, Volume 91, Issue 9, September 2010, pp. 1872-1882.

\subsection{SVC-Sustainable Value Creation}

The author of the paper has proposed the strategy design framework Sustainable Value Creation-SVC. According to the framework, if the organization wants to achieve sustainable value for stakeholders and shareholders, it should:

- Diagnose their current situation-AS-IS situation;

- Discover the opportunities;

- Formulate the action plans;

- Implement the action plans.

The Sustainable Value Creation Framework could be used as a diagnostic tool or guideline to improve organization's strategy. An organization could improve in the four areas defined in this model and could evaluate its improvement process towards the implementation of its sustainable strategy. Such a diagnostic tool creates the possibility to identify certain opportunities and possible areas for improvement in economic, ethical, and environmental terms.

Figure 4 presents the basic components of the shareholder value model presented in two dimensions.

The vertical axis in the model reflects the reference of the organization's activities to the time horizon. The model shows that organizations, while focusing on the current needs, should also take into account the need to create technologies and markets of the future. In the process of creating value for shareholders, the focus should be on the need to achieve short-term results while being focused on generating future growth [27-29].

The horizontal axis reflects the organization's need to develop and protect internal organizational skills and abilities, while targeting the organization's need to use external knowledge.

By juxtaposing these two dimensions, a matrix is created with four different performance dimensions important for creating shareholder value. The lower left quadrant focuses on those aspects of the operation that primarily relate to the internal, short-term goals of the organization, for example, with regard to cost reduction or risk reduction. 


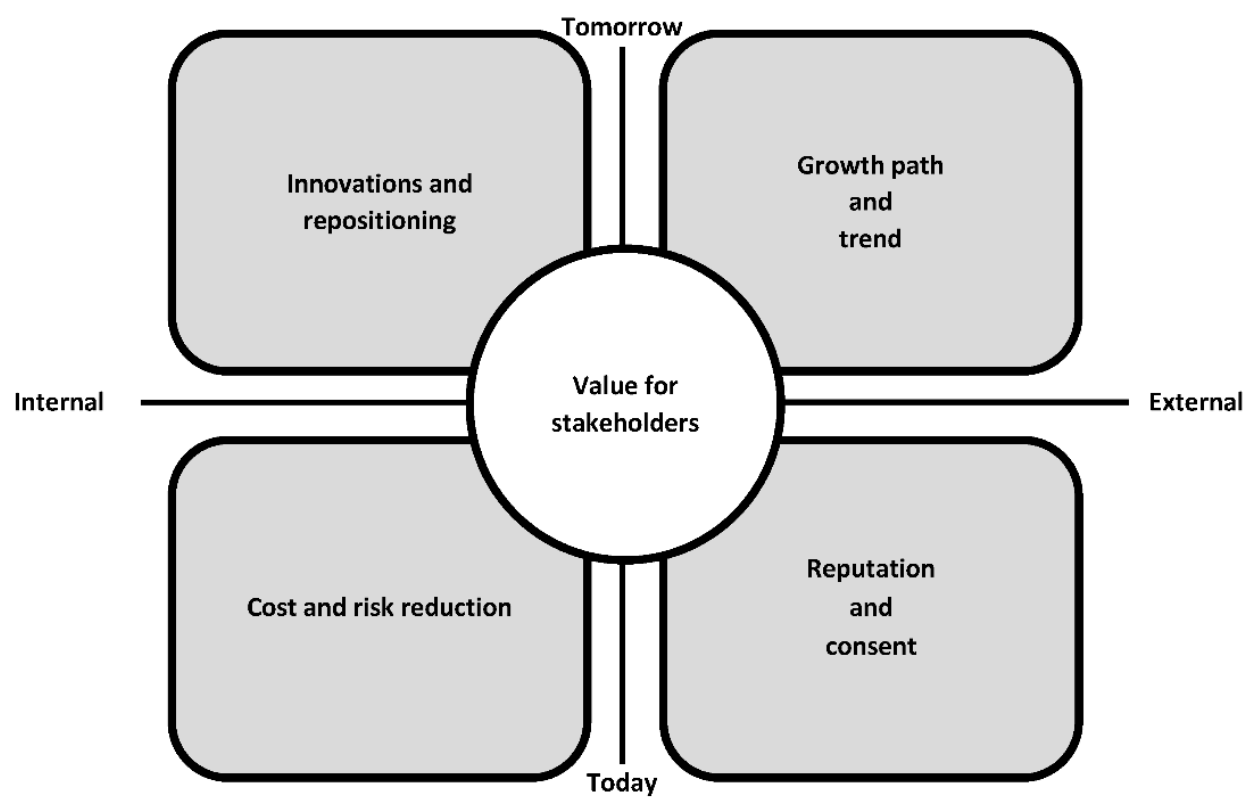

Figure 4. Components of the shareholder value model. Source: Stuart L. Hart and Mark B. Milstein, Creating sustainable value, Academy of Management Executive, 2003, Vol. 17, No. 2, pp. 57.

The lower right quadrant of the matrix focuses on achieving short-term external goals such as striving to improve the reputation and credibility of the organization, which plays a key role in maintaining and increasing shareholder value.

The upper-left quadrant of the matrix focuses on achieving long-term internal goals, such as striving to increase innovation.

The organization should be focused on generating products and services in the future. Internal processes in the organization should be focused on developing or acquiring skills, competences, implementation of modern technologies, and innovations that condition the achievement of future increase in value for the shareholders of the organization.

The top right field of the matrix focuses on the external dimensions related to the achievement of future results. The organization's credible expectations and vision for future growth are key to creating shareholder value. The organization may have the following long-term goals: To offer new products to existing clients or to use previously developed products in new markets. The growth strategy contains guidelines and directions for the development of technologies and products [30].

Figure 5 presents the assumptions of the Sustainable Value Framework.

Organizations should incorporate the indications in all four areas of the model on a continuous basis if they are directed at maximizing shareholder value, similar to the BSC model, where four areas were identified where organizations should focus their activities [31].

Each of the sustainability business strategies and actions have a specific aspect of shareholder value.

Addressing the problems of excessive consumption, waste, and pollution that are related to with industrialization provides an opportunity for organizations to reduce costs and risks by developing pollution reducing skills and capabilities and ensure their eco-efficiency [32]. 


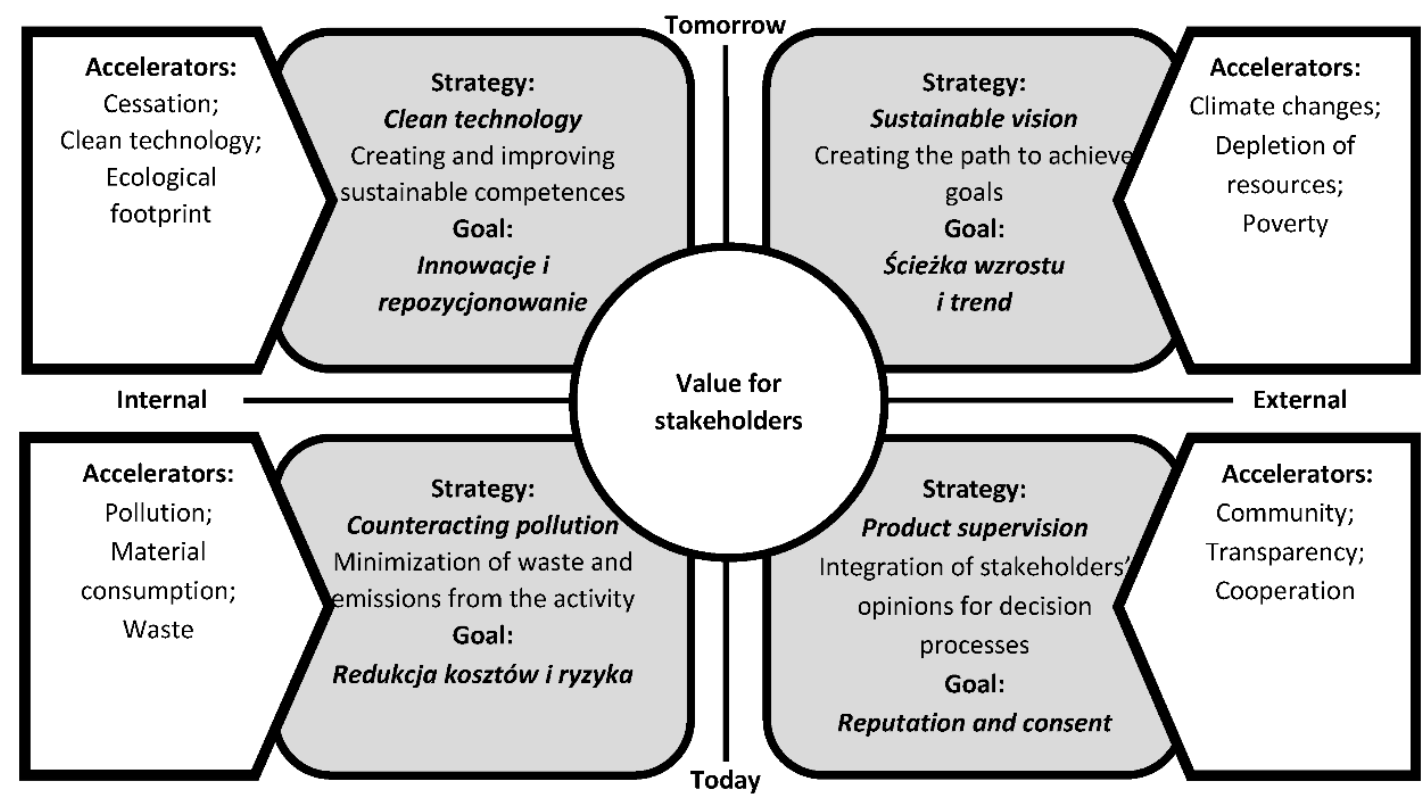

Figure 5. Sustainable Value Framework. Source: Hart S. L., Milstein M. B., Creating sustainable value, Academy of Management Executive, Vol. 17, No. 2, 2003, pp. 60.

The Sustainable Value Framework defines four types of business activities that are related to a specific dimension of shareholder value. The management should incorporate the indications in all four fields of the model simultaneously the effect of maximizing shareholder value could be achieved. The recommended activities include the following:

- Organization's vision of sustainability - the vision should provide guidelines for employees on organizational priorities, technology development strategies, resource allocation, and business even model design. The vision represents all the organization's critical values so it should include all important perspectives: Economic, social, ecological (including that related to energy management). The vision could be inspired by concepts that could be found in the literature, for example the Cradle to Cradle. The three principles of the concept address the most important economic, ecological, and social issues and enable not only reducing emission, energy use, etc., but enable expanding the activities with respect to the business, economic, or ecological environment. The Cradle to Cradle principals are: Waste equals food: That everything is a resource for something else; use of solar energy: That production is based on renewable energy; celebrate diversity: That diversity is valuable [33].

- Pollution prevention strategy-focuses on improving the processes to develop ecoefficiency modern products. Less waste means not only an advantage for the natural environment but also production factors like reducing costs related to either waste disposal or improving the efficiency of raw material use. Effective pollution prevention like other contemporary management trends requires strong employee commitment and a well-developed internal environment for continuous improvement and quality management [34-36].

- Improving compliance with requirements through product management-While pollution prevention is related to internal processes, product compliance is related to the entire product life cycle, from raw material collection, through the manufacturing process, to product application and disposal of used products [37-39]. Ensuring product compliance means the involvement of stakeholders needs: Suppliers, customers, nongovernmental organizations, and the media. The involvement of stakeholders into the organization's processes results in increasing compliance with the requirements and could help to improve the reputation of the organization [40,41]. 
- Accelerating innovation through the use of Clean-Tech-an increasing number of organizations are developing a new generation of "clean technologies" that contribute to their sustainable economic growth. BP and Shell implement investments using solar, wind, and other renewable technologies [42,43].

\subsection{Sustainable Energy Management}

All organizations wishing to meet the challenges that arise in the economic environment and wishing to improve energy management and thus increase energy efficiency should implement the principles of sustainable development and implement the assumptions of the sustainability concept.

The development of energy management systems that meet the requirements of international standards enables organizations to adopt and implement the principles of sustainable energy.

Thanks to the introduction of the energy management system, the organization implements the principle of management transparency, improves the effectiveness of management and investment implementation, and also contributes to the improvement of the image of the organization among its stakeholders.

Implementation of an Energy Management System requires an energy policy, planning, and control process, which is reported as part of the regular management review.

All organizations that want to adapt to changes in the environment should focus on achieving economic, social, and environmental goals.

The world's first energy management standard was created in 2001 in Denmark, and later adopted in Sweden, Ireland, and Spain. In 2009, these standards became the foundations of European standard EN 16001:2009. Between 2009 and 2011, the EN 16001:2009 standard was adopted as the national standard in 30 European countries. In 2011, it was introduced by ISO as ISO 50001 “Energy management systems-Requirements with guidelines for use" and was revised in 2018.

\subsection{Sustainable Energy Management ISO Perspective}

Standard ISO 5001:2018 in Section 3.2.2 defines the energy management system"management system (Section 3.2.1) to establish an energy policy (Section 3.2.4), objectives (Section 3.4.13), energy targets (Section 3.4.15), action plans and process(es) (Section 3.3.6) to achieve the objectives and energy targets" [44].

According to the organization, there are numerous benefits of implementing an energy management system:

(1) ISO 50001 provides a framework and toolkit for efficient energy management in a continuous improvement cycle;

(2) The organization is involved in energy efficiency action plans;

(3) The standard helps an organization to manage many aspects of energy efficiency more accurately;

(4) The implementation of the system guarantees a more precise definition of the energy management mission;

(5) It also helps to involve procurement in the use of energy efficiency as a criterion when selecting suppliers;

(6) It forces the organization to explain the benefits of each independent energy action;

(7) Introduces into a continuous improvement loop [45,46].

As a result of the research, an analysis was conducted regarding the goals implemented in the organizations in the field of climate protection and sustainable development, as well as the importance of goals from the point of view of the strategy implementation. The research results showed that organizations identify the following sustainability goals:

- Electricity production from renewable sources- $76.5 \%$ of the surveyed organizations set this goal;

- Reduction of the carbon footprint-67.6\%;

- Achieving zero emissions within the prescribed period-67.6\%; 
- $\quad$ Production of heat from renewable energy sources-64.7\%.

As a result of the research, it was also determined which part of the organization defines the environmental goals listed below in its strategy:

- Increasing the share of renewable sources in energy consumption-91.2\% of organizations declared the achievement of this goal;

- Profit generation-88.2\%;

- Achieving climate neutrality (reduction and/or balancing of CO2) $-88.2 \%$;

- $\quad$ Saving resources and materials-88.2\%;

- $\quad$ Training of employees in environmental issues-85.3\%;

- $\quad$ Energy saving-82.4\%;

- Monitoring the company's carbon footprint-79.4\%.

\subsection{Primary Research Results}

To identify the key goals that organizations considered the most important (Figure 6). The participants asked to evaluate the seven most common goals: Profit generation, training employees in environmental issues, energy saving, increasing the share of renewable sources in energy consumption, monitoring the company's carbon footprint, achieving climate neutrality (reducing and/or balancing $\mathrm{CO} 2$ emissions), saving resources and materials. Figure 6 shows the indicator (expressed in \%), which shows how many organizations considered the indicated goals to be important and very important, these goals were assessed on a five-point scale at 4 and 5 .

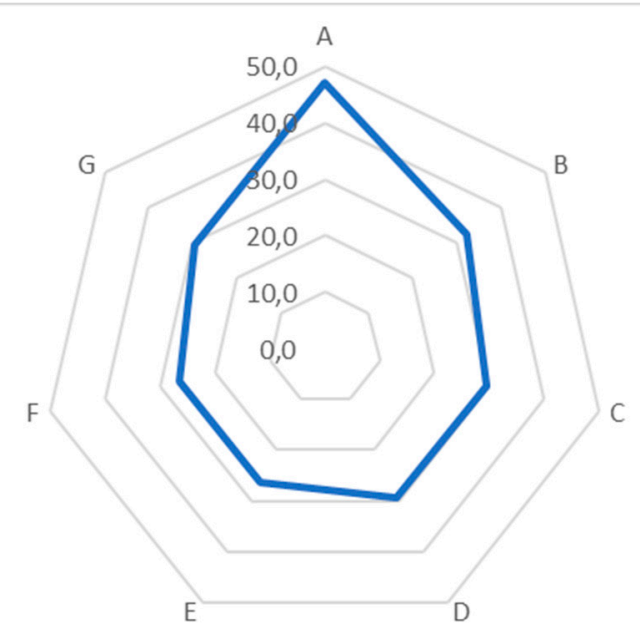

Figure 6. Percentage of organizations that assessed the indicated goals as significant and very important from the point of view of the implementation of their strategy (4-significant and 5-very significant). Legend: A-Profit generation, B-Training employees in environmental issues, Cenergy saving, D-Increasing the share of renewable sources in energy consumption, E-monitoring the company's carbon footprint, F-achieving climate neutrality (reducing and/or balancing CO2 emissions), G—saving resources and materials. Source: Own study, 2021.

The most important goals were: Generating profit-47.1\%, training employees in environmental issues-32.4\%, saving energy-29.4\%, increasing the share of renewable sources in energy consumption-29.4\%, saving resources and materials-29.4\%. The organization's focus on economic goals is very closely related to other goals, as organizations look for ways to minimize operating costs. The cost of energy is an important item in the economic bill of almost every company. If it is too high, it has a negative impact on the development of the enterprise and limits its investments. Therefore, investments in obtaining energy 
from renewable sources, in addition to optimizing consumption costs, are also of great importance for the company's image.

According to Claudiu-Ionut CREȚU-SÂRBU [47], we cannot imagine the modern world without energy, just as we cannot imagine the modern world destroyed by excessive energy consumption. Therefore, we must be effective at all levels: Individual, organizational, social, political, institutional. Developing and maintaining energy efficiency means meeting common goals such as sustainable economy (cost savings) and purity of the environment (reduction of harmful greenhouse gas emissions). Effective energy management becomes a necessity.

As a result of the conducted research, key activities supporting the process of sustainable energy management in the analyzed organizations were also identified. Such activities include: Planning activities aimed at reducing energy consumption at the stage of formulating the organization's strategy; providing financial resources for activities aimed at reducing energy consumption; analysis of investment costs, potential savings at the level of general energy costs, possible subsidies; analysis of technical aspects: Availability of resources such as wind, solar energy or biomass, availability of project partners; analysis of regulatory aspects: Regulatory obligations and the possibilities or limitations in obtaining permits; energy efficiency measurement; commitment of top management; investing in appropriate equipment and solutions; staff training; building awareness among employees to reduce energy consumption.

The results of the research showed that only $5.9 \%$ of organizations do not plan activities aimed at reducing consumption at the stage of formulating the organization's strategy, while other organizations consider it to be an important aspect of their activities. When it comes to providing financial resources for activities aimed at reducing energy consumption, most organizations (85.3\%) financially support such activities, and only $14.7 \%$ declared no activities in this area. Effective implementation of energy management is possible thanks to the analysis of investment costs, potential savings at the level of general energy costs, possible subsidies, and analysis of technical aspects: Availability of resources such as wind, solar energy, or biomass, and availability of project partners; research has shown that $82.4 \%$ of organizations carry out such analyses. The analysis of regulatory aspects (regulatory obligations and the possibilities or limitations in obtaining permits) is performed by $82.4 \%$ of the surveyed organizations; measuring energy efficiency is done by $79.4 \%$ of organizations; commitment to the top management is shown by $88.2 \%$. Moreover, $85.3 \%$ of the analyzed organizations invest in appropriate equipment and solutions, training employees and building awareness among employees in the field of reducing energy consumption.

Figure 7 presents the average assessment of the scope of support by the indicated activities of the sustainable energy management process.

When analyzing the average score among the listed activities, the highest scores were given to activities consisting of building awareness among employees in terms of reducing energy consumption, measuring energy efficiency, analyzing regulatory aspects (regulatory obligations and the possibility or limitations in obtaining permits), the involvement of the top management, and employee training.

Organizations assessed the range of support provided by the indicated measures of the sustainable energy management process as good and very good: Measuring energy efficiency - 41.2; building employee awareness to reduce energy consumption-41.2, employee training - 38.2; investing in appropriate equipment and solutions-35.3.

The results of research on the identification of environmental indicators and the degree of their use by organizations in order to achieve sustainability and development in the organization show that the surveyed organizations monitor 28 indicators. 


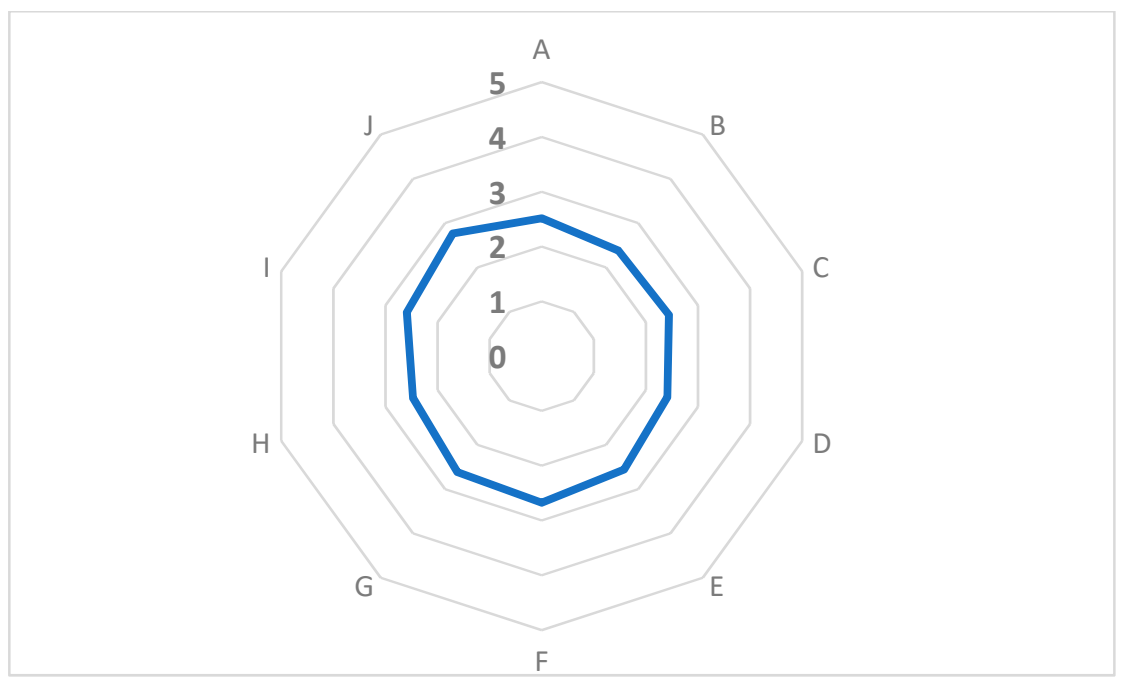

Figure 7. Average assessment of the scope of support by the indicated activities of the sustainable energy management process ( 0 -no support; 1 - support to a very small extent; 5 - support to a very large extent). Legend: A-planning activities aimed at reducing consumption at the stage of formulating the organizational strategy; B-providing financial resources for activities aimed at reducing energy consumption; $\mathrm{C}$-analysis of investment costs, potential savings at the level of general energy costs, possible subsidies; D—analysis of technical aspects: availability of resources such as wind, solar energy or biomass, availability of project partners; E-analysis of regulatory aspects: regulatory obligations and the possibilities or limitations in obtaining permits; F-energy efficiency measurement; $\mathrm{G}$ - top management commitment; $\mathrm{H}$-investing in appropriate equipment and solutions; I-employee training; J—building employee awareness of reducing energy consumption. Source: own study, 2021.

Two groups can be identified among environmental indicators: Obligatory and optional indicators. In the group of obligatory indicators, nine indicators were indicated (Figure 8 and Table 1).

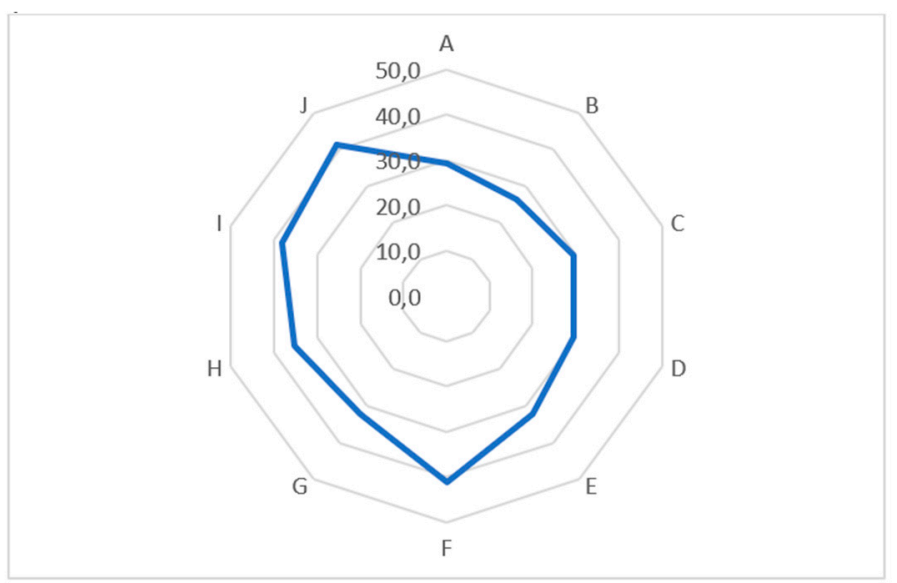

Figure 8. The number of organizations that assessed the scope of support as good and very good by the indicated activities of the sustainable energy management process (4-support to a large extent and 5-support to a very large extent). Legend: A-activities aimed to reduce consumption planned at the stage of formulating the organization's strategy; B-providing the sufficient financial resources for activities aimed to reduce energy consumption; C - analysis of investment costs, potential savings at the level of general energy costs or possible subsidies; D-analysis of technical aspects: availability of resources such as wind, solar energy or biomass, availability of project partners; E-analysis of regulatory aspects: regulatory obligations and the possibilities or limitations in obtaining permits; 
F-energy efficiency measurement; G-commitment of top management; $\mathrm{H}$-investing in appropriate equipment and solutions; I-employee training; J-building employee awareness of reducing energy consumption. Source: own study, 2021.

Table 1. Characteristics of the examined indicators-obligatory environmental indicators. Source: Own study, 2021.

\begin{tabular}{cccc}
\hline Symbol & Name & \% ind. & WRO \\
\hline DWMP & Disposal and Waste Management Policy & 98.6 & 0.92 \\
GELT & Amount and types of gases released into the air & 90.2 & 0.84 \\
DELT & Amount and types of dust released into the air & 87.6 & 0.84 \\
ACSWR & Quantity, Condition and Composition of Solid Waste & 85.6 & 0.81 \\
EC & Energy consumption & 80.0 & 0.90 \\
WLQQT & Amount and quality, and type of water samples & 69.1 & 0.80 \\
ACSR & Amount, condition and composition of the discharged sewage & 57.5 & 0.74 \\
ATFU & Amount and type of fuel used & 49.6 & 0.84 \\
LU & Land development & 46.0 & 0.50 \\
\hline
\end{tabular}

Among this group of indicators, the analyzed organizations measured (Table 1): DWMP—Disposal and waste management policy with the number of responses of $98.6 \%$; GELT - the amount and types of gases released into the air-90.2\%; DELT—amount and types of dust released into the air-87.6\%; ACSWR — quantities, condition, and composition of solid waste- $85.6 \%$; EC — energy consumption- $80.0 \%$; WLQQT-quantity, quality, and type of sampled water-69.1\%; ACSR-amount, condition, and composition of the released sewage- $57.5 \%$; ATFU—amount and type of fuel consumed-49.6\%; and LUland utilization- $46 \%$.

These indicators are obligatory; however, not for all organizations, which results from the fact that fees for using the environment are charged only after exceeding a certain level specified in the relevant laws and regulations, relating to mandatory indicators.

The analysis of the relative assessment indicator shows that all indicators in this group were considered very important.

The next group were optional environmental indicators. This group included 24 indicators, 19 of which were indicated as measured and monitored in the analyzed organizations.

The most frequently measures and monitored indicators in the analyzed organizations were: ES — energy sources used (99.8\%); DP—availability of written environmental procedures (87.4\%); LEI-local environmental problems (88.6\%); ENCC—cost of failure to comply with environmental laws $(78.7 \%)$; TLEI-total level of environmental investments $(74.7 \%)$; ECI—initiatives to reduce energy consumption $(68.67 \%)$; ECV—energy saving $(68.8 \%)$.

The least frequent measures and monitored indicators in the analyzed organizations were: ETP—transport policy and statistics (31.6\%); BPI-impact of products/services on the environment and biodiversity (25.64\%); N-noise level (16.1\%); REA-risk of environmental accidents (15.6\%); MT-toxicity of materials (3.4\%).

None of the organizations measured the following indicators: ECOEDU-eco-education; APU—amount of paper used; PACRI—packaging reduction initiatives; $C E$-number of ecological certificates; T \& L-transport and logistics, including routing and consolidation and fleet management.

At the same time, when analyzing the Relative Assessment Index (WRO), the organizations recognized the following indicators as the most important: LEI-local environmental problems (WRO—0.94); ECV—energy saving (WRO—0.98); and WCVS—water use savings (WRO-0.94).

There is a need for research aimed at improving the sustainable energy management strategy in building lasting value for stakeholders. 
The topic of sustainable development and improving energy management has been studied in various sectors of the economy, including transport, production, information and communication, and agriculture [47].

António da Silva Gonçalves, Mil-Homens dos Santos, focusing on sustainability, energy efficiency, and the fundamentals of energy management, carried out a detailed analysis of the ISO 50001 energy management system from the point of view of sustainability. The purpose of the analysis was to assess the effectiveness of its implementation, identify the existence of gaps, and develop improvements capable of filling the identified gaps. The effectiveness and results of the implementation of ISO 50001: 2011 combined with the construction of an ideal energy management system allowed to identify four gaps and transform them into six potential improvements [48].

The measurement of indicators in terms of achieving the organization's goals is a factor determining the improvement of the organization. The Global Reporting Initiative (GRI) guidelines are an international reporting benchmark for corporate responsibility and sustainable development.

The purpose of the GRI Reporting Framework is to create a generally accepted framework for reporting economic, environmental, and social aspects of the organization's functioning [49-51].

The term "Energy Efficiency Integration Practices" appears in the literature, which is related to the presence of corporate practices and policies aimed at managing energy consumption, the use of incentives to save energy, and the assessment of the effects of these practices and policies. Energy efficiency integration practices are directly related to economic and social factors. So, it seems that management of energy consumption is effective not only in economic aspects such as cost reduction, but also in social aspects such as interaction with stakeholders and improvement of the image of the organization in the community (Bunse et al. [52], Thollander and Ottosson [53-55]).

Liu et al. [56] and Antunes, Carreira, and Silva [57] propose a model of energy consumption management, the use of which improves energy efficiency in organizations.

The author of the study plans to deepen the research carried out towards more detailed analyses of the energy efficiency of organizations in Poland. The subject of the research entails limitations in its conduct, among which there are factors related to keeping company secrets. The author will strive to identify further factors that will take into account the power of enterprises when making economic decisions.

\section{Conclusions}

All the goals that were set up in the paper were completed:

- According to the role of stakeholders in strategy developing process, it has to be mentioned that clients either customers or organizations are the most important among stakeholders and play the most important role in organization's strategy development process. So, to improve energy efficiency among enterprises, great potential lies in educating the final clients either B2B or B2C model about relations between energy efficiency and environmental protection. The most effective tool to improve country economy energy efficiency could be incorporating energy efficiency importance in the purchasing process;

- According to the strategy management frameworks that could be used as fundamentals to develop strategy by any organization and hep them to achieve better energy efficiency, there are few frameworks that are incorporating either economic or economic or social and environmental issues including energy management. The author introduces her own framework here, SVC (Sustainable Value Creation);

- $\quad$ Regarding to the key factors in improving your sustainable energy management strategy, according to the research the most important factors to implement energy management strategy are: Training employees in environmental issues; energy saving; and increasing the share of renewable sources in energy consumption. The research results also confirm the findings of similar research done by the author several years ago; 
- To identify the key actions supporting the process of sustainable energy management, the research results indicate the most common actions include energy efficiency measurement, employee training, and building employee awareness of reducing energy consumption. These are the basic activities that are undertaken at the beginning of the path to active environmental management including energy efficiency management;

- To identify the environmental indicators used by organizations and their degree of use and sustainability in the organization, the research results indicate that the most common indicators include: Disposal and waste management policy; amount and types of gases released into the air; and amount and types of dust released into the air. Like in the previous point, the basic indicators show that the respondents were in beginning on the path to active environmental management including energy efficiency management.

The practical outcome of the paper is that the organization's leaders and workers responsible for environmental and energy issues could estimate the current stage of energy efficiency and what strategy framework to use to improve their operations.

Further research will be done on leadership and the leader's role in implementing energy efficiency into organizations operations.

Funding: This research is funded by the "Determinanty doskonalenia zarzadzania w aspekcie społecznej odpowiedzialności organizacj" research project funded by War Studies University, Poland.

Institutional Review Board Statement: Not applicable.

Informed Consent Statement: Not applicable.

Data Availability Statement: Data sharing not applicable.

Conflicts of Interest: The author declare no conflict of interest.

\section{References}

1. Gilliland, M. How to Avoid Wasting Time at Forecasting; SAS Institute Inc.: Cary, NC, USA, 2013.

2. Camillo, F.; Conti, V.; Ghiselli, S. Integration of Different Data Collection Techniques Using the Propensity Score. Almalaurea Working Papers No. 4. 2011. Available online: https:/ /ideas.repec.org/p/laa/wpaper/4.html (accessed on 3 April 2021).

3. Batorski, D.; Olcoń, M. Conducting research over the Internet: Basic methodological issues. Studia Socjol. $2007,3$.

4. Hewson, C.; Yule, P.; Laureat, D.; Kogel, C. Internet Research Methods. In A Practical Guide for Social and Behavioral Sciences; Sage Publications: London, UK, 2003.

5. Zając, J.M.; Batorski, D. How to Get People to Participate in Online Surveys: Increasing Sample Performance; Psychologia Społeczna No. 3; 2007.

6. Urbaniak, M. Directions of Improvement of Quality Management Systems; Publishing House of the University of Lodz: Lodz, Poland, 2010; p. 145.

7. Harrison, J.S.; Caron, H.S.J. Strategic Management of Organizations and Stakeholders: Concepts, 2nd ed.; South-Western College Publishing: Cincinnati, OH, USA, 1998.

8. Freeman, R.E. Strategic Management: A Stakeholder Approach; Pitman: Boston, MA, USA, 1984.

9. Vroom, V.H.; Yetton, P. Leadership and Decision Making; University of Pittsburgh Press: Pittsburgh, PA, USA, 1973.

10. Rugman, A.M.; Verbeke, A. Corporate strategies and environmental regulations: An organizing framework. Strateg. Manag. J. 1998, 19, 363-375. [CrossRef]

11. Pojasek, R.B. A Framework for Business Sustainability. Environ. Qual. Manag. 2007, 17, 81-88. [CrossRef]

12. Grudzewski, W.M.; Hejduk, I.K.; Sankowska, A.; Wańtuchowicz, M. Sustainability in business-the enterprise of the future. In Changes in Paradigms and Management Concepts; POLTEXT: Warsaw, Poland, 2010.

13. Azapagic, A. Systems approach to corporate sustainability-A general management Framework. Process Saf. Environ. Prot. 2003, 81, 303-316. [CrossRef]

14. Razzaghipour, A. The Need for Efficiency of Energy Sources Management in Sustainable Architecture. J. Hist. Cult. Art Res. 2021, 10, 16-27. [CrossRef]

15. CEC. Eurostat Measuring Progress Towardsa More Sustainable Europe, Sustainable Development Indicators for the European Union; Office for Official Publications of the European Communities: Luxembourg, 2005; pp. 1-5.

16. Pinter, L.; Hardi, P.; Bartelmus, P. Sustainable Development Indicators: Proposals for a Way Forward. Discussion Paper Prepared under a Consulting Agreement on Behalf of the UN Division for Sustainable Development; IlSD: Winnipeg, MB, Canada, $2005 ; \mathrm{pp} .1-11$.

17. Seliger, G. Sustainability in Manufacturing, Recovery of Resources in Product and Material Cycles; Springer: Berlin/Heidelberg, Germany; New York, NY, USA, 2007. 
18. Seliger, G.; Severengiz, S.; Weinert, N. Sustainable Industrial Value Creation Nets. In Proceedings of the 15th CIRP International Conference on Life Cycle Engineering, Sydney, Australia, 17-19 March 2008; pp. 1-4.

19. Daily, G. Natures Services: Societal Dependence on Natural Ecosystems; Island Press: Washington, DC, USA, 1997.

20. Hawken, P.; Lovins, A.; Lovins, H. Natural Capital Is Creating the Next Industrial Revolution; Little Brown \& Company: Boston, MA, USA, 1999.

21. Rheingold, H. Smart Mobs: The Next Social Revolution; Perseus Publishing: Cambridge, MA, USA, 2002.

22. Hart, S.; Milstein, M. Global sustainability and the creative destruction of industries. Sloan Manag. Rev. 1999, 41, $23-33$.

23. Easterly, W. The Elusive Quest for Growth; MIT Press: Cambridge, MA, USA, 2001.

24. Holton, I.; Glass, J.; Price, A.D.F. Managing for sustainability: Findings from four company case studies in the UK precast concrete industry. J. Clean. Prod. 2010, 18, 152-160. [CrossRef]

25. Wicks, A.C. Overcoming the separation thesis: The need for a reconsideration of business and society research. Bus. Soc. 1996, 35, 104. [CrossRef]

26. Emerson, H. The Twelve Principles of Efficiency; The Engineering Magazine Co.: New York, NY, USA, $1924 ;$ pp. $190-201$.

27. Christensen, C. The Innovators Dilemma; Harvard Business School Press: Boston, MA, USA, 1998.

28. Schumpeter, J. Capitalism, Socialism and Democracy; Harper Torchbooks: New York, NY, USA, 1942.

29. Foster, R.; Kaplan, S. Creative Destruction; Doubleday: New York, NY, USA, 2001.

30. Hart, S.L.; Milstein, M.B. Creating sustainable value. Acad. Manag. Exec. 2003, 17, 56-67. [CrossRef]

31. Kaplan, R.; Norton, D. The balanced scorecard-Measures that drive performance. Harv. Bus. Rev. 1992, 72, 71-79.

32. DeSimone, L.; Popoff, F. Eco-Efficiency: The Business Link to Sustainable Development; MIT Press: Cambridge, MA, USA, 1997.

33. Hart, S. A natural resource-based view of the firm. Acad. Manag. Rev. 1995, 20, 986-1014. [CrossRef]

34. Christmann, P. Effects of best practices of environmental management on cost advantage: The role of complementary assets. Acad. Manag. J. 1998, 43, 663-680.

35. Sharma, S.; Vredenburg, H. Proactive corporate environmental strategy and the development of competitively valuable organizational capabilities. Strateg. Manag. J. 1998, 19, 729-753. [CrossRef]

36. Roome, N.; Hinnells, M. Environmental factors in the management of new product development. Bus. Strategy Environ. 1993, 2, 12-27. [CrossRef]

37. Welford, R. Environmental Strategy and Sustainable Development; Routledge: London, UK, 1995.

38. Steger, U. Managerial issues in closing the loop. Bus. Strategy Environ. 1996, 5, 252-268. [CrossRef]

39. Wheeler, D.; Sillanpaa, M. The Stakeholder Corporation; Pittman Publishing: London, UK, 1997.

40. Elkington, J. Cannibals with Forks; New Society Publishing: Gabriola Island, BC, Canada, 1998.

41. McDonough, W.; Braungart, M. Cradle to Cradle; North Point Press: New York, NY, USA, 2002.

42. Prahalad, C.K. The Fortune at the Bottom of the Pyramid. In Eradicating Poverty Through Profits; Wharton School Publishing: Philadelphia, PA, USA, 2010; pp. 207-216.

43. Prahalad, C.K.; Hart, S.L. The Fortune at the Bottom of the Pyramid. Strategy Bus. 2002, 26, 1-14. [CrossRef]

44. ISO 50001:2018. Energy Management Systems—Requirements with Guidance for Use; ISO: Geneva, Switzerland, 2018.

45. da Silva Gonçalves, V.A.; Mil-Homens Dos Santos, F.J. Energy management system ISO 50001:2011 and energy management for sustainable development. Energy Policy 2019, 133, 110868. [CrossRef]

46. Reis, C.; Benvenutti, L.; Campos, L.; Uriona, M. The Influence of Company Size on Energy Management Systems Adoption: A System Dynamics Model. Braz. Bus. Rev. (Port. Ed.) 2020, 17, 579-600. [CrossRef]

47. Crețu-Sârbu, C. Zero Hour for Climate Action. Intelligent decision-making for sustainable management of energy, emerg: Energy. Environ. Effic. Resour. Glob. 2020, 6, 121.

48. Pilipczuk, O. Sustainable Smart Cities and Energy Management: The Labor Market Perspective. Energies 2020, 13, 6084. [CrossRef]

49. Global Reporting Initiative (GRI). Guidelines for Sustainability Reporting (Diretrizes Para Relatório de Sustentabilidade). 2006. Available online: http:/ / www.globalreporting.org (accessed on 3 April 2021).

50. Global Reporting Initiative (GRI). Mining and Metals Sector Supplement. 2010. Available online: https://www.globalreporting. org/resourcelibrary /GRI-G4-Mining-and-Metals-Sector-Disclosures.pdf (accessed on 3 April 2021).

51. Global Reporting Initiative (GRI). G4 Sustainability Reporting Guidelines. 2014. Available online: https:/ /www.globalreporting. org/resourcelibrary/GRIG4-Part1-Reporting-Principles-and-Standard-Disclosures.pdf (accessed on 3 April 2021).

52. Bunse, K.; Vodicka, M.; Schönsleben, P.; Brülhart, M.; Ernst, F.O. Integrating energy efficiency performance in production management: Gap analysis between industrial needs and scientific literature. J. Clean. Prod. 2011, 19, 667-679. [CrossRef]

53. Thollander, P.; Ottosson, M. Energy management practices in Swedish energy-intensive industries. J. Clean. Prod. 2010, 18, 1125-1133. [CrossRef]

54. Perlin, A.P.; Gomes, C.M.; Kneipp, J.M.; Motke, F.D. Practices of energy use management and sustainable performance in Brazilian mineral industries. Environ. Qual. Manag. 2018, 27, 143-153. [CrossRef]

55. Dai, H.; Jiang, B.; Hu, X.; Lin, X.; Wei, X.; Pecht, M. Advanced battery management strategies for a sustainable energy future: Multilayer design concepts and research trends. Renew. Sustain. Energy Rev. 2021, 138, 110480. [CrossRef] 
56. Liu, X.; Niu, D.; Bao, C.; Suk, S.; Shishime, T. A survey study of energy saving activities of industrial companies in Taicang, China. J. Clean. Prod. 2012, 26, 79-89. [CrossRef]

57. Antunes, P.; Carreira, P.; Silva, M.M. Towards an energy management maturity model. Energy Policy J. 2014, 73, 803-814. [CrossRef] 